\title{
AQP1 in Red Blood Cells of Uremic Patients during Hemodialytic Treatment
}

\author{
M. Buemia F. Floccaria G. Di Pasquale ${ }^{b}$ G. Cutroneo ${ }^{c}$ A. Sturiale ${ }^{a}$ \\ C. Aloisia A. Ruello ${ }^{a}$ A. Romeo ${ }^{a}$ A. Favaloro ${ }^{c}$ F. Corica ${ }^{a} \quad$ N. Frisina ${ }^{a}$ \\ G. Anastasic
}

aDepartment of Internal Medicine, bInstitute of Pediatrics, and 'Department of Biomorphology and Biotechnologies, University of Messina, Italy

\section{Key Words}

Aquaporin $1 \cdot$ Hemodialysis $\cdot$ Red blood cells

\begin{abstract}
Hemodialysis influences the transport of water through the erythrocytic membrane, and induces morphologic and functional modifications. Recently water channels, called aquaporins (AQP), have been identified on the membrane of red blood cells. The aim of the present study was, therefore, to evaluate any relationships between volumetric changes in erythrocytes (MCV), plasma osmolarity and membrane expression of AQP1 in 22 uremic patients during a hemodialysis session, and compare value with those in a control group of 22 healthy volunteers. Membranal AQP1 expression was evaluated using three methods: indirect immunofluorescence under confocal microscopy, immunoenzymatic method after membrane extraction, and immunoblotting. In uremic subjects, at baseline membrane AQP1 expression was significantly lower, whereas plasma osmolality was higher than in controls. At 1 and $2 \mathrm{~h}$ of replacement therapy, a progressive increase was observed in erythrocytic AQP1, values similar to those in controls being attained after $3.5 \mathrm{~h}$. During the session osmolality values reduced progressively, becoming significantly lower than basal
\end{abstract}

values. The mean erythrocytic corpuscular volume in patients with ESRD was significantly lower than in cntrols at baseline. This value increased during hemodialysis, attaining statistical significance with respect to the basal value at $3.5 \mathrm{~h}$ of dialysis. Close correlations were found between plasma osmolality and AQP1 values ( $r=$ -0.930; $p<0.05$ ), and also between MCV and plasma osmolality trend $(r=-0.909 ; p<0.05)$. There was a linear correlation $(r=0.63, p<0.05)$ between plasma AVP concentrations and plasma osmolality. The variations found in plasma osmolarity during hemodialysis, may induce AQP1 expression on the membrane of intact red blood cells.

Copyright $\odot 2002$ S. Karger AG, Basel

\section{Introduction}

Uremic patients undergoing hemodialysis show an increase in mean cellular volume (MCV) and in sodium content, while erythrocytic deformability and viability are improved [1-3]. Although this may depend on several factors (e.g. removal of uremic toxins, such as polyamines, or an increase in blood $\mathrm{pH}$ ), water movement is probably the main cause of $\mathrm{MCV}$ variations [4].

\begin{tabular}{ll}
\hline KARGER & ( ) 2002 S. Karger AG, Basel \\
Fax +4161306 1234 $34-2766 / 02 / 0924-0846 \$ 18.50 / 0$ \\
$\begin{array}{l}\text { E-Mail karger@karger.ch } \\
\text { www.karger.com }\end{array}$ & $\begin{array}{l}\text { Accessible online at: } \\
\text { www.karger.com/journals/nef }\end{array}$
\end{tabular}

Prof. Michele Buemi

Via Salita Villa Contino, 30, Pal. Bianca

I-98100 Messina (Italy)

Tel. +39090 2212396, Fax +390902935162

E-Mail Buemim@Unime.it/Asrael@worldmailer.com 
Human erythrocytes are highly permeable to water. Until recently, small uncharged molecules, such as water, were believed to pass freely across the lipidic bi-layer. However, tissue membranes can restrict the movement of small uncharged molecules, selective channels being required to allow the flow of these small nonelectrolytes [5]. In 1991, Smith and Agre [6] identified the first waterselective channel. This abundant protein, called aquaporin1 (AQP1) [6], is now known to be the main major erythrocytic transporter of water, as proven by the reduced water permeability in erythrocytes from Colton -/AQP1 null humans and from transgenic AQP1-null mice [7].

The aim of the present study was therefore to investigate the possible relations between volumetric changes in red blood cells (RBC), plasma osmolality, and AQP1 in $\mathrm{RBC}$ during a hemodialysis session.

Membrane expression of AQP1 was studied using: (1) indirect immunofluorescence on confocal microscopy; (2) an immunoenzymatic method after extraction of the membrane, and (3) immunoblotting.

\section{Material and Methods}

We studied 22 anuric ESRD patients (11 females, 11 males; mean age, $52.2 \pm 16$ years, mean body weight $59.2 \pm 4.4 \mathrm{~kg}$ ). The patients were on regular HD at the same outpatients' clinic and all had given their fully informed consent. None of them were diabetic or had previous malignancy, cardiac failure, pulmonary edema, and/or liver disease. ESRD was due to interstitial nephropathy (5 patients), hypertensive nephrosclerosis (10 patients) and chronic glomerulonephritis (7 patients). Patients were clinically stable when enrolled. A specially trained dietician interviewed each patient and estimated the patients' daily nutrient intake by means of a 3-day dietary report. The control group consisted of 22 healthy volunteers ( 11 females, 11 males; mean age $30.3 \pm 10.5$ years; mean body weight $58.8 \pm$ $4.8 \mathrm{~kg})$.

\section{Hemodialysis}

Patients were fasted overnight and they had breakfast $1 \mathrm{~h}$ after the beginning of the session. Every ESRD patient underwent a midweek, 3.5-hour morning session of HD, which was processed using standard bicarbonate, $5.5 \mathrm{mM}$ glucose containing dialysate and a high permeability AN-69 dialyser (Crystal 2800 or 3400, Hospal, Italy) with a surface of 1.2-1.6 $\mathrm{m}^{2}$. All patients underwent dialysis three times a week, for $27 \pm 9$ months (from 5 to 54 months). The mean inter-dialytic increase in body weight was $3.2 \mathrm{~kg}$ (minimum 2, maximum 4). Blood and dialysate flows were set at a constant 250-300 and $500 \mathrm{ml} / \mathrm{min}$, respectively. The ultrafiltration flow rate was constant throughout the session and the total ultrafiltrated volume was $<3.5$ liters for each subject. The recirculation flow rate was $<5 \%$ for each patient. The temperature was set at $37^{\circ} \mathrm{C} . \mathrm{Kt} / \mathrm{V}$ urea was $1.2 \pm$ 0.1 and the mean hemoglobin $12.5 \pm 0.3 \mathrm{~g} / \mathrm{dl}$.

AQP in RBC of Uremic Patients

undergoing Hemodialysis

\section{Blood Sampling}

Whole blood samples were collected via the arterial needle at time 0 (just after the beginning of the HD session), and 1.2 and $3.5 \mathrm{~h}$ from the start of the session and immediately chilled on ice. An aliquot of each sample was microcentrifuged for $10 \mathrm{~min}$ and the hematocrit measured. Red blood cell (RBC) parameters and indices, such as $\mathrm{MCV}$, were determined in duplicate by means of blood counter TOA-Sysmex E-4000 (Medical Electronics Co. Ltd., Kobe, Japan).

RBC were washed three times in PBS, $0.15 M \mathrm{NaCl}$ pH 7.4 saline. $1 \mathrm{ml}$ of packed red cells were incubated with $4 \mathrm{ml}$ of distilled water for $10 \mathrm{~min}$ at $4{ }^{\circ} \mathrm{C}$ and then centrifuged at $4,200 \mathrm{~g}$ for $20 \mathrm{~min}$ at $4^{\circ} \mathrm{C}$. The hemolysate of each sample was stored at $-80^{\circ} \mathrm{C}$. Intraerythrocytic $\mathrm{Na}^{+}$and $\mathrm{K}^{+}$contents were determined in $\mathrm{RBC}$ lysate, obtained by adding $20 \mathrm{ml}$ of saponine solution $20 \%$ [8].

Plasma was collected with centrifugation $\left(1,200 \mathrm{~g}, 20 \mathrm{~min}, 4^{\circ} \mathrm{C}\right)$, white cells were removed as reported elsewhere [8] and plasma was stored at $-20^{\circ} \mathrm{C}$ until determination of plasma $\mathrm{Na}^{+}$and $\mathrm{K}^{+}$and osmolality. Plasma ions (sodium, potassium), as well as arterial $\mathrm{pH}$, were determined using a standardized procedure, whereas $\mathrm{Na}$ and $\mathrm{K}$ assessment for RBC were achieved following the method described by Brugnara et al. [2]. Plasma osmolality was determined using the Osmostat OM-6020 apparatus (Kagaku, Co., Ltd., Kyoto, Japan).

\section{Plasma Vasopressin}

Plasma AVP concentrations were measured using an AVP radioimmunoassay kit (Peninsula Laboratories, Belmont, Calif., USA). C18 Sep-Pak extraction was performed prior to the assay procedure. The minimum detection level was $0.5 \mathrm{pmol} / \mathrm{l}$. The coefficients of variation were $13 \%$ (inter-assay) and $9 \%$ (intra-assay).

\section{Red Blood Cell AQP1}

Immunofluorescence. Red blood cells were smeared onto glass slides. Samples were fixed in acetone/methanol (1:2) and incubated for $30 \mathrm{~min}$ at room temperature with PBS containing 1\% BSA. After washing three times in PBS, $0.15 \mathrm{M} \mathrm{NaCl}$, samples were incubated with AQP1 antiserum (Sigma Chemicals, St. Louis, Mo., USA) diluted to 1:30 in PBS containing 1\% BSA, for $1 \mathrm{~h}$ at room temperature. Slides were rinsed with PBS, $0.15 \mathrm{M} \mathrm{NaCl}$ and incubated with antirabbit FITC 1:50 (Sigma Chemicals) in PBS containing 1\% BSA, for $30 \mathrm{~min}$ at room temperature for visualization by confocal microscopy. The sections were then examined and photographed using a Zeiss LSM 510 confocal microscope, which had an argon laser $(458,488 \lambda)$ and two He-Ne lasers (543 and $633 \lambda)$. The images collected were digitised at a resolution of 8 bits into an array of $2,048 \times$ 2,048 pixels. Optical sections of fluorescence specimens were obtained using an He-Ne laser (543 nm) and an Argon laser (458 nm) at a scanning speed of $1 \mathrm{~min} 2 \mathrm{~s}$ at an average of up to 8 .

The stocks of images obtained were processed using different software functions: (1) Splitting - separation of images scanned in the channels and the composite images in a common window, (2) Projection - overlapping of single optical sections to obtained a $3 \mathrm{D}$ reconstruction in their full thickness, (3) Rotation - rotation at different angles of the images of the whole sample or of its parts.

Elisa Assay. Elisa assay was performed as described elsewhere [16]. $1 \mathrm{ml}$ of whole blood was washed three times in an isotonic washing buffer (PBS, $0.15 \mathrm{MNaCl}$, glucose $5 \mathrm{mM}$ ) and then centrifuged at $500 \mathrm{~g}$ for $10 \mathrm{~min}$.

One gram of glass beads (Sigma Chemicals, G-4649) were then added to $250 \mu \mathrm{l}$ of red cells in a washing buffer at a dilution of $1: 2$ and $4 \mathrm{ml}$ of lysis buffer (Tris- $\mathrm{HCl} 50 \mathrm{mM}$ acidized with formic acid at $\mathrm{pH}$ 
Table 1. Results

\begin{tabular}{|c|c|c|c|c|c|}
\hline & Control & Basal & $60 \mathrm{~min}$ & $120 \mathrm{~min}$ & $180 \mathrm{~min}$ \\
\hline Arterial pH & $7.33 \pm 0.03$ & $7.34 \pm 0.04$ & $7.40 \pm 0.02$ & $7.40 \pm 0.03$ & $7.46 \pm 0.04 *$ \\
\hline Osm, mosm/1 & $306.38 \pm 1.88$ & $339.10 \pm 1.00^{\circ}$ & $329.27 \pm 2.24^{*}, \circ$ & $323.35 \pm 2.54^{*, \circ}$ & $320.54 \pm 1.30 *$ \\
\hline AQP-1, ng/ml & $5.6 \pm 0.9$ & $3 \pm 0.75^{\circ}$ & $3.6 \pm 0.83^{\circ}$ & $4.4 \pm 0.89^{*}, \circ$ & $5 \pm 0.91^{*}$ \\
\hline $\mathrm{AVP}, \mathrm{pg} / \mathrm{ml}$ & $2.35 \pm 0.4$ & $4.45 \pm 0.25^{\circ}$ & $3.47 \pm 0.45^{\circ}, *$ & $3.01 \pm 0.31^{\circ}, *$ & $2.49 \pm 0.49 *$ \\
\hline $\mathrm{pNa}^{+}, \mathrm{mEq} / \mathrm{l}$ & $138.10 \pm 4.05$ & $138.00 \pm 3.25$ & $136.16 \pm 2.05$ & $137.64 \pm 3.00$ & $138.55 \pm 3.00$ \\
\hline $\mathrm{PK}^{+}, \mathrm{mEq} / \mathrm{l}$ & $4.20 \pm 1.14$ & $5.49 \pm 0.70$ & $5.00 \pm 0.70$ & $4.67 \pm 0.35$ & $3.42 \pm 0.44^{*}$ \\
\hline $\mathrm{cNa}^{+}, \mathrm{mEq} / 1$ & $29.88 \pm 7.88$ & $21.60 \pm 6.50$ & $22.50 \pm 7.33$ & $23.02 \pm 7.54$ & $26.11 \pm 6.36^{*}$ \\
\hline $\mathrm{CK}^{+}, \mathrm{mEq} / 1$ & $79.34 \pm 9.03$ & $95.70 \pm 7.36$ & $97.03 \pm 6.77$ & $98.91 \pm 7.86$ & $100.21 \pm 6.62^{\circ}$ \\
\hline $\mathrm{MCV}, \mathrm{fl}$ & $101.41 \pm 5.00$ & $96.03 \pm 4.95$ & $97.05 \pm 3.43$ & $99.99 \pm 5.79$ & $102.23 \pm 4.03^{*}$ \\
\hline $\mathrm{MCHC}, \mathrm{g} / \mathrm{dl}$ & $34 \pm 1.3$ & $32 \pm 1.3^{\circ}$ & $31.8 \pm 1^{\circ}$ & $31.6 \pm 1.5^{\circ}$ & $31 \pm 0.7^{\circ}, *$ \\
\hline
\end{tabular}

${ }^{*} \mathrm{p}<0.05$ vs. basal value; ${ }^{\circ} \mathrm{p}<0.05$ vs. controls.

Values expressed as means \pm SEM, were recorded in patients and controls at 0,60, 120 and $180 \mathrm{~min}$.

5.5). Samples were then put into a mixer (International PBI) for $60 \mathrm{~min}$ in ice until lysis was complete. They were then centrifuged at $4^{\circ} \mathrm{C}$ at $10,000 \mathrm{~g}$ for $10 \mathrm{~min}, 750 \mu \mathrm{l}$ of extraction buffer (Tris- $\mathrm{HCl}$ $50 \mathrm{~m} M$, NDSB201 $1 M$ Fluka, Digitonine $0.05 \%$, EDTA $0.1 M$, pepstatine, leupeptine $5 \mu \mathrm{g} / \mathrm{ml}$, PMSF $0.2 \mathrm{mM}$ ) were added to each and then mixed for $60 \mathrm{~s}$ in a mixer on ice and centrifuged at $4^{\circ} \mathrm{C}$ $(10,000 \mathrm{~g}$ for $5 \mathrm{~min}) .250 \mu \mathrm{l}$ of extract was passed onto a Sephadex G25 micro-column (Sigma Chemicals), pre-equilibrated in Tris-buffer $\mathrm{pH} 7.4$, and stored at $-80^{\circ} \mathrm{C}$.

Control Peptide. AQP1 and affinity pure anti-AQP1 antibodies generated in rabbits, diluted in Tris buffer $\mathrm{pH} 7.4$ at $1 \mathrm{mg} / \mathrm{ml}$, were supplied dehydrated by Sigma Chemicals.

Biotinylation of affinity pure antibodies was performed using the Biotin tag-MicroBiotinylation kit (Sigma Chemicals).

Calibrator Diluent. Tris buffer pH 7.4 with $20 \mathrm{~g} / \mathrm{l} \mathrm{BSA}, 0.15 \mathrm{M}$ $\mathrm{NaCl}, 0.05 \%$ Triton X100.

Conjugate Buffer. Tris buffer containing $15 \mathrm{~g} / 1 \mathrm{BSA}, 15 \mathrm{~g} / \mathrm{l}$ sodium caseinate, $0.15 \mathrm{M} \mathrm{NaCl}, 0.02 \%$ Triton X100 passed through a $0.45-\mu \mathrm{m}$ filter.

Aquaporin Calibrators. The AQP1 control peptide was added to a calibrator diluent until the working concentration range had been achieved. The minimal detectable quantity of AQP1 was $0.5 \mathrm{ng} / \mathrm{ml}$.

Assay Procedure. Flat-bottomed MicroElisa plates (Nunc Covalink, Denmark) were coated overnight at $4{ }^{\circ} \mathrm{C}$ with a $200 \mu \mathrm{l} /$ well of affinity pure antibody diluted to $5 \mu \mathrm{l} / \mathrm{ml}$ in a coating buffer $(0.1 \mathrm{M}$ sodium carbonate/bicarbonate buffer, $\mathrm{pH}$ 9.6), then washed three times with a wash buffer (TBS pH 7.4 with $0.15 \mathrm{M} \mathrm{NaCl}$, Triton X100), blocked with $250 \mu \mathrm{l} /$ well of blocking buffer (BSA $30 \mathrm{~g} / \mathrm{l}$ in TBS with $\mathrm{NaCl} 0.15 \mathrm{M}, \mathrm{pH} 7.4$ ) and incubated for $1 \mathrm{~h}$ at $37^{\circ} \mathrm{C}$, washed five times and stored dry at $4^{\circ} \mathrm{C}$. The AQP1 control peptide, used as a calibrator, was added to a calibrator diluent to achieve the working concentration range. Calibrators and samples ( $200 \mu \mathrm{l})$, added in duplicate to coated wells and incubated for $2 \mathrm{~h}$ at $37^{\circ} \mathrm{C}$, were washed four times. $200 \mu \mathrm{l}$ of biotinylate rabbit affinity pure antibody, 1:1,000 diluted in conjugated buffer were applied to each well. After 2 hours' incubation at $37^{\circ} \mathrm{C}$, the plate was washed four times and filled with $200 \mu \mathrm{l} /$ well of avidine conjugated with alkaline phosphatase (Sigma), diluted to 1:1,000 in conjugate buffer and incubated for $1 \mathrm{~h}$ at $37^{\circ} \mathrm{C}$. After being washed four times, $200 \mu \mathrm{l} /$ well of $p$-nitrophenylphosphate substrate solution in diethanolamine buffer pH 9.5 was added and the absorbance values read at $492 \mathrm{~nm}$.

AQP1 Calibration Curve. Absorbance values from the microwells calibrated with a known concentration of AQP1 were used to construct the calibration curve from five points corresponding to different AQP1 concentrations of the calibrated standard.

The limit of detection was defined as the lowest concentration that corresponded to the mean nonspecific absorbance of the conjugate.

\section{Statistical Analysis}

All data are expressed as mean \pm SEM. For serial measurement of each compound throughout the dialysis session, analysis of variance for repeated measures was performed. If an overall statistical difference was observed, the presence of a statistically different significance between any time points was determined by the post-hoc Scheffé test. $\mathrm{p}<0.05$ was considered significant.

\section{Results}

The mean arterial blood pressure and weight changes observed during hemodialysis are shown in table 1 and 2 .

\section{Blood pH}

There was a progressive increase in blood $\mathrm{pH}$ increase during the hemodialytic session. This datum attained statistical significance only at the third hour of hemodialysis $(\mathrm{p}<0.05)$.

\section{Plasma Osmolality}

Uremic subjects had higher basal values than controls. During the hemodialytic session, the values decreased 


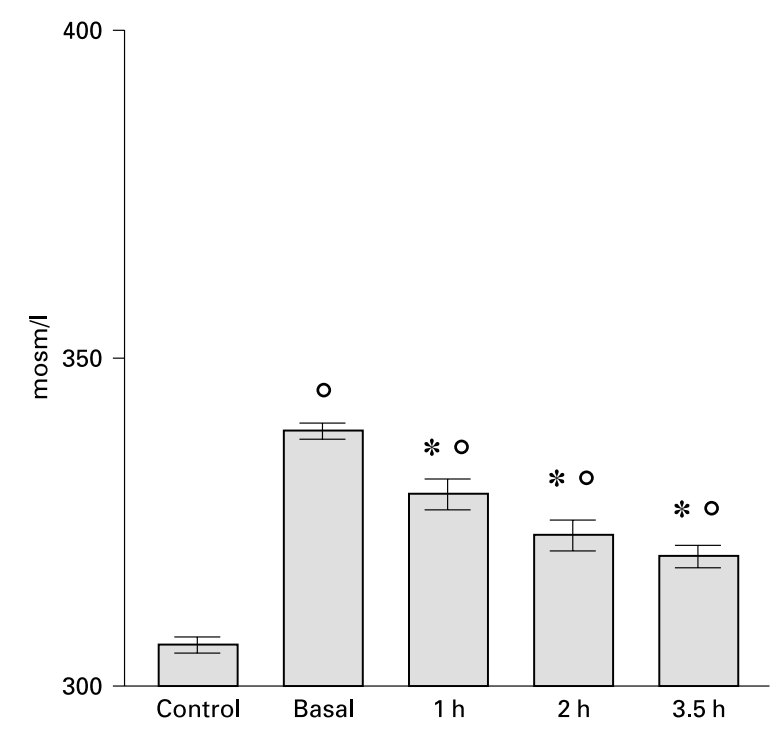

Fig. 1. Plasma osmolality. Values are expressed as means \pm SEM, recorded in controls and in patients at the beginning and at 1,2 and $3.5 \mathrm{~h}$ of the dialysis session. ${ }^{*} \mathrm{p}<0.05$ vs. baseline; ${ }^{\circ} \mathrm{p}<0.05$ vs. control.

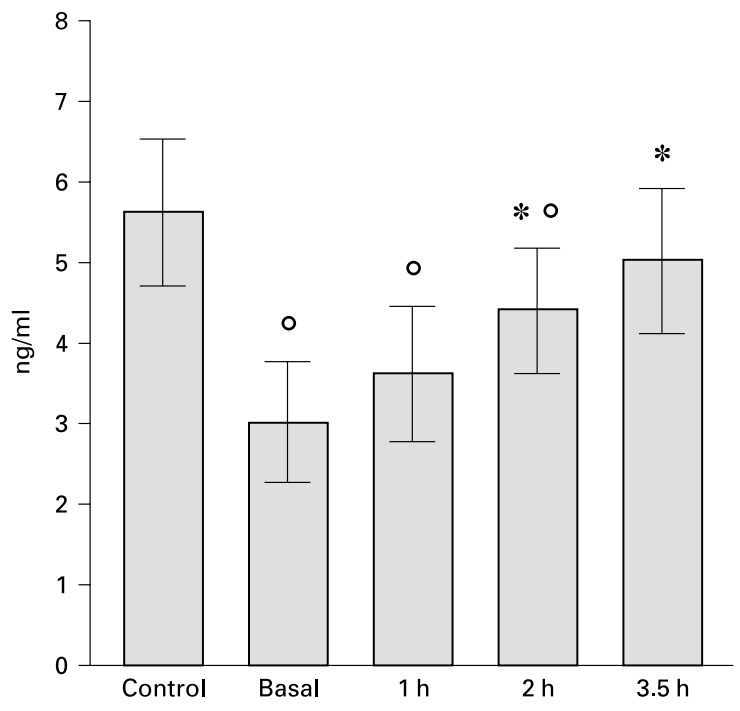

Fig. 2. Erythrocytic AQP1. Values are expressed as means \pm SEM, recorded in controls and in patients at the beginning and then at 1,2 and $3.5 \mathrm{~h}$ of the dialysis session. ${ }^{*} \mathrm{p}<0.05$ vs. baseline; ${ }^{\circ} \mathrm{p}<0.05$ vs. control.

Table 2. Age, body weight and mean blood pressure

\begin{tabular}{|c|c|c|c|c|c|c|}
\hline & \multicolumn{2}{|l|}{ Pre-HD } & \multicolumn{2}{|l|}{ Post-HD } & \multicolumn{2}{|l|}{ Controls } \\
\hline & male & female & male & female & male & female \\
\hline Age, years & $41 \pm 14^{\circ}$ & $64 \pm 12^{\circ}$ & $41 \pm 14^{\circ}$ & $64 \pm 12^{\circ}$ & $25 \pm 7$ & $29 \pm 9$ \\
\hline Body weight, $\mathrm{kg}$ & $64 \pm 1.4$ & $51.7 \pm 0.8$ & $61.7 \pm 0.9$ & $49.1 \pm 0.9$ & $61.8 \pm 0.7$ & $50.1 \pm 0.6$ \\
\hline Mean arterial pressure, $\mathrm{mm} \mathrm{Hg}$ & $123 \pm 6$ & $120 \pm 7$ & $110 \pm 7$ & $109 \pm 8$ & $104 \pm 5$ & $103 \pm 4$ \\
\hline
\end{tabular}

Values, expressed as means \pm SEM, were recorded in controls and in patients at the beginning and end of the dialysis session. $*$ p $<0.05$ vs. pre-HD; ${ }^{\circ} \mathrm{p}<0.05$ vs. control.

progressively in a significant manner with respect to the basal condition $(p<0.05)$, and did not reach the mean control value, even after HD.

\section{Plasma Vasopressin (fig. 1)}

Uremic subjects presented higher basal values for plasma vasopressin than the control group $(\mathrm{p}<0.05)$. At 2 and $3.5 \mathrm{~h}$ of HD the study, values decreased progressively with respect to values at the beginning of the session $(\mathrm{p}<$ $0.05)$.

\section{Aquaporin 1 (fig. 2, 3)}

At baseline, the membrane detection of AQP1 was significantly lower in uremic patients than in controls (fig. 3 , pictures $3 \mathrm{a}, \mathrm{b}, \mathrm{c})$. After 1 and $2 \mathrm{~h}$ of HD, AQP1 expression progressively increased (fig. 3 , pictures $4 \mathrm{a}, \mathrm{b}$, c and $5 \mathrm{a}, \mathrm{b}$, c), reaching values within the normal range only at $3.5 \mathrm{~h}$ $(\mathrm{p}<0.05)$ (fig. 3, pictures 6a, b, c).

The optical sections on left row show the fluorescence imaging, the optical sections on central row show transmitted light imaging and the optical sections in right row

Nephron 2002;92:846-852 

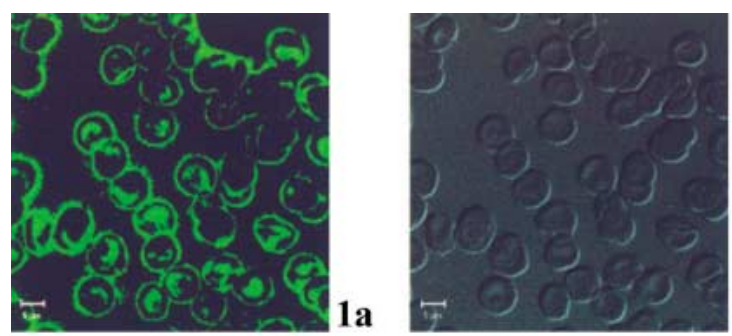

$1 b$
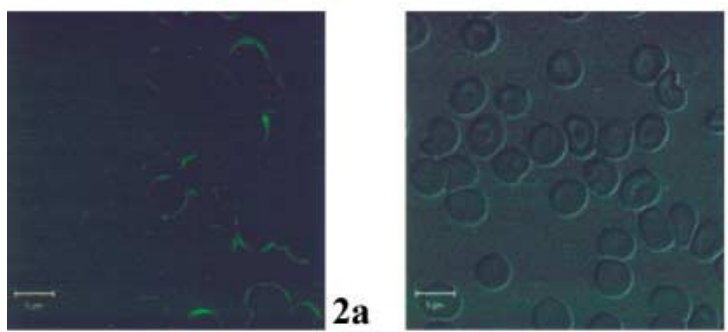

2b
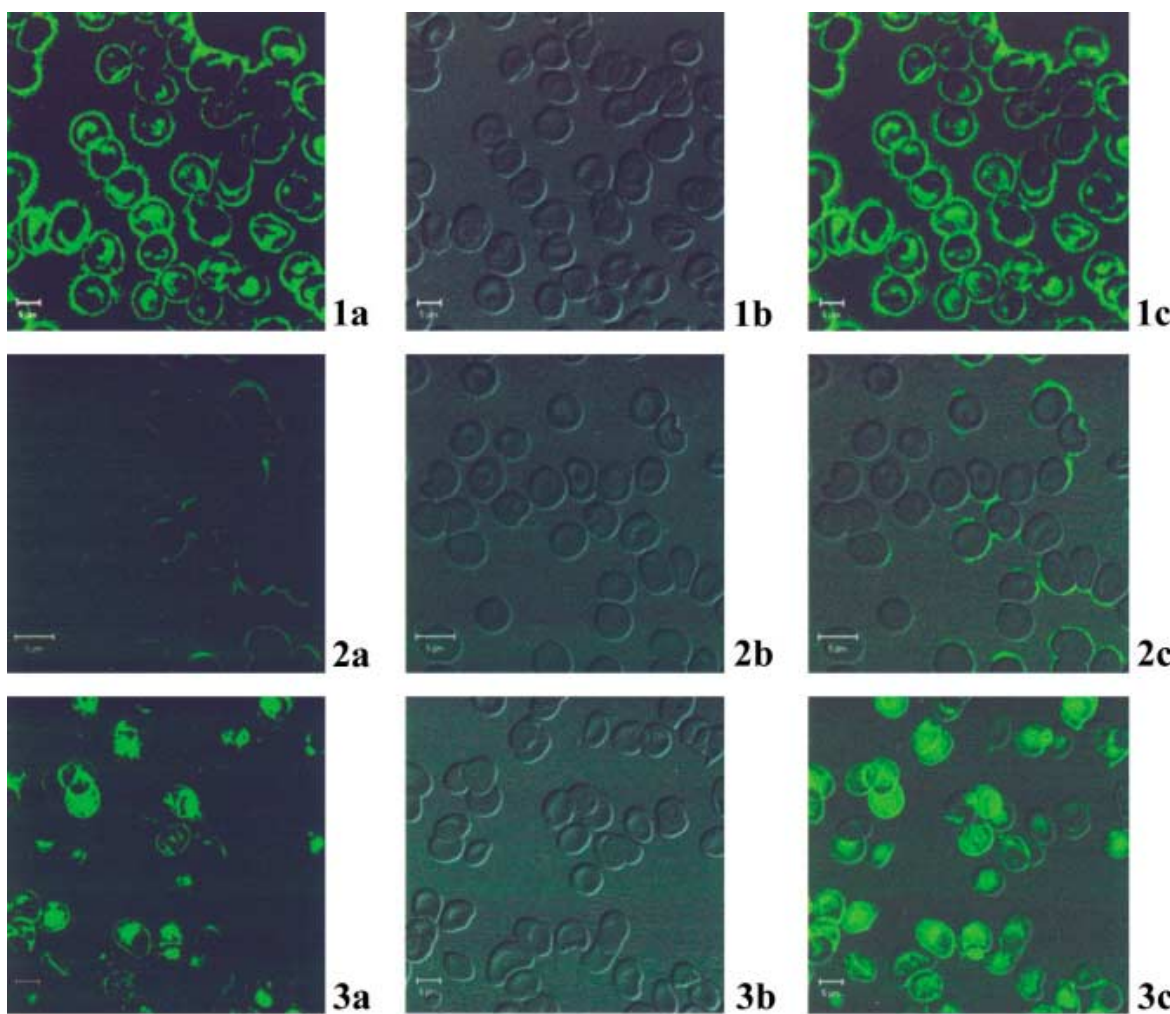

3b
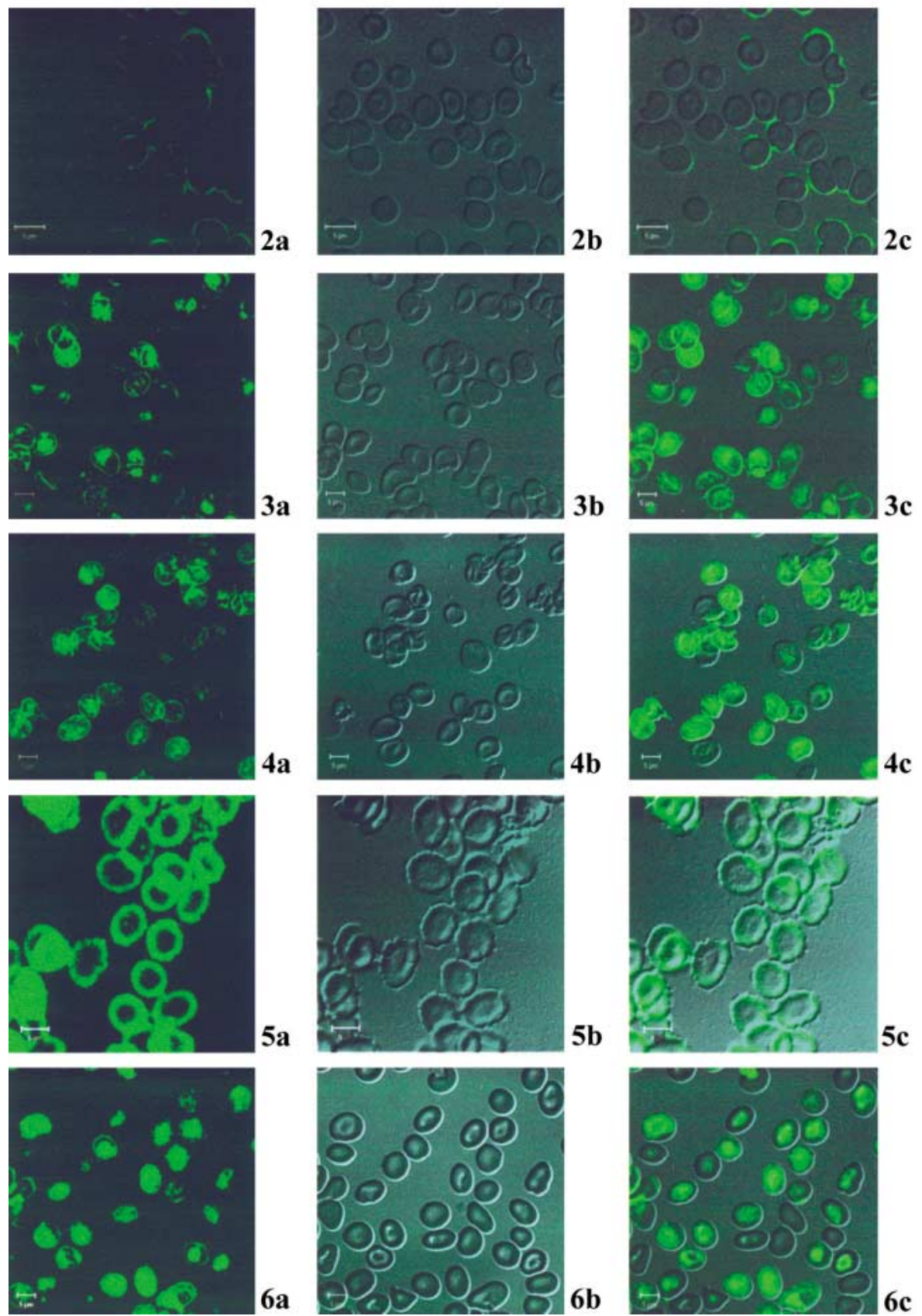

$6 b$

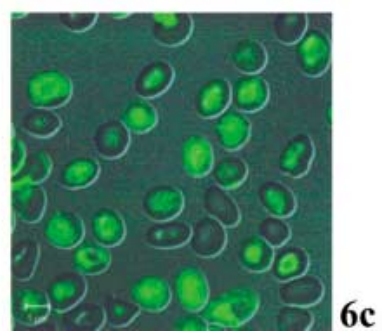


show the overlapping of fluorescence and transmitted light imaging. Pictures 1a, b, c (fig. 3) show normal values of anti-AQP1 Ab in control subjects. Pictures $2 \mathrm{a}, \mathrm{b}, \mathrm{c}$ exhibit the values on erythrocyte from control subjects without anti-AQP1 Ab (negative control).

\section{Mean Cell Volume and Mean Cell Hemoglobin}

Whereas MCV was significantly lower $(\mathrm{p}<0.05)$ in uremic patients than in controls, it was significantly higher than the basal value at $3.5 \mathrm{~h}$ of dialysis $(\mathrm{p}<0.05)$. At $3.5 \mathrm{~h}$ of dialysis, $\mathrm{MCH}$ showed a progressive decrease with respect to baseline values $(\mathrm{p}<0.05)$.

\section{$\mathrm{K}^{+}$and $\mathrm{Na}^{+}$Concentrations}

At the end of HD, uremic patients presented a significant reduction in plasma $\mathrm{K}^{+}\left(\mathrm{pK}^{+}\right)$, while no significant variations were found in plasma $\mathrm{Na}^{+}\left(\mathrm{pNa}^{+}\right)$. A significant increase was found in cytosolic $\mathrm{K}^{+}\left(\mathrm{cK}^{+}\right)$and $\mathrm{Na}^{+}\left(\mathrm{cNa}^{+}\right)$ at the end of the HD session with respect to the baseline values.

Close correlations were observed between plasma osmolality and AQP1 $(r=-0.930 ; p<0.05)$; changes in MCV were related to plasma osmolality $(\mathrm{r}=-0.909 ; \mathrm{p}<$ $0.05)$ trends. A linear correlation $(r=0.63, p<0.05)$ was found between the plasma AVP concentration and plasma osmolality.

\section{Discussion}

Hemodialysis can be considered the mass transfer of substances between plasmatic water and dialysis fluid, occurring through diffusion and modulated by a membrane [9]. The flow across dialysis membrane is the first step in a long series of flows through membranes dividing the different compartments of the human body. Our aim was to study erythrocytes as a simplified model of tissue, already studied in many researches on membrane fluxes [10]. As these cells are totally immersed in plasma, they are continuously exposed to all electrolytic plasma modifications due to uremia or to the presence of dialysis fluid [11].

In the present study, the baseline values for plasma osmolality in uremic patients were higher than in controls, probably because of the presence of uremic toxins, which may modify erythrocytic deformability and viability [12]. The finding that baseline plasma AVP concentrations were higher in uremic patients suggests that in patients on hemodialysis, changes in plasma osmolality play a predominant role in determining AVP secretion, in agreement with Fasanella D'Amore et al. [13]. At confocal microscopy, lower erythrocytic levels of AQP1 were found in uremic subjects than in controls. This finding was confirmed by data obtained with the quantitative ELISA method. That AQP1 expression is different in red blood cells appears to be confirmed by the trend for MCV, levels being lower in uremic subjects than in controls.

During the dialysis session there was a progressive reduction in plasma osmolality, while plasma AVP and red blood cell AQP1 expression showed a progressive increase. This increased expression of water channels may trigger modifications in the erythrocytic morphology observed at this time. In fact, a significant increase was observed in the mean corpuscular volume until the end of the hemodialysis session $(3.5 \mathrm{~h})$. We therefore suggest that as they pass through AQP1 pores, molecules of water may cause an increase in cellular volume, evident also in the reduction in $\mathrm{MCH}$ observed in the present study.

AVP, a polypeptide regulating water resorption and salt transport with a strong constrictor effect on vascular smooth muscle cells, acts through binding to two specific membrane receptors. The V2 receptors, isolated in the medullary portion of the kidney, act by stimulating adenylate cyclase to produce cAMP, causing phosphorylation of protein kinase A (PKA). The PKA-induced phosphorylation of aquaporin 2 (AQP2) water channels is associated with a 'trafficking' of these channels from subapical aggregates to apical membranes of collecting duct principal cells, leading to an increase in permeability to water $[15,16]$.

Several authors observed that AQP1 does not appear to be regulated from any pathways. The findings of Jenq et al. [17] on cultured mIMCD cells appear to demonstrate that AQP1 over-expression on the membrane is induced by a culture medium at a high osmolality. In a murine peritoneal dialysis model, Carlsson et al. [18] observed that AQP1 is crucial to trans endothelial water transport induced by crystalloid osmosis. AQP1 deletion in mice produces distinct forms of nephrogenic diabetes insipidus, characterized by an inability to concentrate urine under water restriction [19].

Although we found a close correlation between plasma AVP, plasma osmolality and AQP1 expression, the antidiuretic hormone may not play a role in the regulation of membrane AQP1 expression: AVP receptors are not present in erythrocytes [14]. Unlike peritoneal and renal tubular cells, erythrocytes have no nucleus, and so they cannot produce new $A Q P 1$ proteins in response to a trigger. It is therefore highly unlikely that an intracellular AQP1 trafficking might occurs in these cells. The increase in AQP1 expression might represent a steric variation in the molecular morphology of this water channel. 
AQP1 is a homotetramer in which each monomer interacts with two neighboring monomers through membrane-spanning alpha helices. Interactions between loops may contribute to tetramer stability, thus constituting the molecular basis for the response of AQP1 to osmotic variations, through protein structure modifications [20, 21]. Mechanical forces may affect erythrocytes during the dialytic circuit and modify the cytoskeleton, integral proteins and membrane lipidic compounds, thus inducing lateral diffusion AQP1 movements in the red blood cell membrane, as observed by Cho et al. [22]. The increase in AQP1 on the red blood cell membrane, observed by us, may be due to steric variations in water channel molecules potentially leading to a greater activation [20] and to an increased exposure of AQP1 epitopes.

Several authors have demonstrated that in uremic patients there are plasmatic substances that alter membrane pump functions and that hemodialysis can revert these effects $[23,24]$. It has yet to be demonstrated whether these substances can activate morphometric variations on the AQP1 molecule.

In conclusion, erythrocytic AQP1 expression, which is lower in uremic than in nonuremic patients, increases during a dialysis session and is positively correlated to the increase in $\mathrm{MCV}$ and negatively correlated to variations in plasma osmolarity.

\section{References}

1 Stabellini G, Bosi GP, Valeno V, Pellati A, Soffritti E, Masotti M, Fiocchi O, Calastrini C, Ricci G: Relation between the osmolality trend and ornithyne-decarboxylase activity in red blood cells of uremic patients during hemodialytic treatment. Biomed Pharmacother 1998; 52:166-168.

2 Brugnara C, Kruskall MS, Johnstone MR: Membrane properties of erythrocytes in subjects undergoing multiple blood donations with or without recombinant erythropoietin. $\mathrm{Br} \mathrm{J}$ Haematol 1993;84:118-130.

3 Oh MS, Levison SP, Carrol HJ: Content and distribution of water and electrolytes in maintenance hemodialysis. Nephron 1975;14:421432.

4 Gellert R, Billip-Tomecka Z, Bogdanska-Straszynska B, Malecka B, Sicinski A: Intradialytic erythrocyte volume changes. Nephrol Dial Transplant 1991;6(suppl 3):10-13.

5 Agre P, Bonhivers M, Borgnia MJ: The aquaporins blueprints for cellular plumbing systems. J Biol Chem 1998;273.

6 Smith BL, Agre P: Erythrocyte Mr28.000 transmembrane protein exists as a multisubunit oligomer similar to channel proteins. J Biol Chem 1991;266:6407-6415.

7 Yang B, Ma T, Verkman AS: Erythrocyte water permeability and renal function in double knockout mice lacking aquaporin-1 and aquaporin-3. J Biol Chem 2001:276:624-628.

8 Corica F, Ientile R, Allegra A, Romano G, Cangemi F, Di Benedetto A, Buemi M, Cucinotta D, Ceruso D: Magnesium levels in plasma, erythrocyte and normotensive patients with type II diabetes mellitus. Biol Trace Element Res 1996;51:13-21.
9 Sargent JA, Gotch FA: Principles and biophysics of dialysis; in Drukker W, Parson FM, Maher JF (eds): Replacement of Renal Function by Dialysis. Boston, 1978 vol 3, pp 38-68.

10 Quarello F, Boero R, Guarena C, Rosati C, Girando G, Giacchino F, Piccoli G: Acute effects of hemodialysis on erythrocyte sodium fluxes in uremic patients. Nephron 1985;41: 22.

11 Flemming SJ, Cattel WR: Red cell volume and plasma sodium. Nephron 1985;41:126.

12 Calzavara P, De Angeli S, Nieri A, Furlan C, Bolzonella R, Da Porto A: Alterations in erythrocyte morphology induced by blood pumps. J Artif Organs 1993;16:653-658.

13 Fasanella D'Amore T, Wauters JP, Waeber B, Nussberger J, Brunner HR: Response of plasma vasopressin to changes in extracellular volume and/or plasma osmolality in patients on maintenance hemodialysis. Clin Nephrol 1985; 23:299-302.

14 Buemi M, Corica F, Di Pasquale G, Aloisi C, Sofi M, Casuscelli T, Floccari F, Senatore M, Corsonello A, Frisina N: Water immersion increases urine excretion of aquaporin-2 in healthy humans. Nephron 2000;85:20-26.

15 Buemi M, D’Anna R, Di Pasquale G, Floccari F, Ruello A, Aloisi C, Leonardi I, Frisina N, Corica F: Urinary excretion of aquaporin-2 water channel during pregnancy. Cell Physiol Biochem 2001;11:203-208.

16 Nielsen S, Kwon T, Christensen BM, Promeneur D, Frokiaer J, Marples D: Physiology and pathophysiology of renal aquaporins. J Am Soc Nephrol 1999;10:647-663.

17 Jenq W, Mathieson IM, Ihara W, Ramirez G: Aquaporin-1: An osmo-inducible water channel in cultured mIMCD-3 cells. Biochem Biophys Res Commun 1998;245:804-809.
18 Carlsson O, Nielsen S, Zakaria el-R, Rippe B: In vivo inhibition of transcellular water channels (aquaporin-1) during acute peritoneal dialysis in rats. Am J Physiol 1996;271:H2254$\mathrm{H} 2262$.

19 Ma T, Song Y, Yang B, Gillespie A, Carlson EJ Epstein CJ, Verkman AS: Nephrogenic diabetes insipidus in mice lacking aquaporin-3 water channels. Proc Natl Acad Sci USA 2000; 97:5434-5439.

20 Cheng W, Wang CX, Chen WZ, Xu, YW, Shi YY: Investigating the dielectric effects of channel pore water on the electrostatic barriers of the permeation ion by the finite difference Poison-Boltzamann method. Eur Biophys J 1998; 27:105-112.

21 Murata K, Mutsuoka K, Hirai T, Walz T, Agre P, Heymann JB, Engel A, Fujiyoshi Y: Structural determinants of water permeation through aquaporin-1. Nature 2000;407:599_ 605.

22 Cho MR, Knowles DW, Smith BL, Moulds JJ, Agre P, Mohandas N, Golan DE: Membrane dynamics of the water transport protein aquaporin-1 in intact human red cells. Biophys $\mathrm{J}$ 1999; 76:1136-1144.

23 Krzezinski JM, Godon JP, Rorive GL: Erythrocyte sodium-potassium activities, plasma natriuretic activity, and peripheral vascular resistances during hemodialysis or hemofiltration. $\mathrm{J}$ Clin Hypertens 1985; 1:245-256.

24 Prasad R, Mond R, Jain S, Kaur G, Chugh KS: Modulation of ouabain sensitive sodium potassium pump of erythrocytes from patients with chronic renal failure: role of acute hemodialysis. Biochem Mol Biol Int 1996;40:1087-1094. 